\title{
Antidiarrheal Activity of Three Medicinal Plants in Swiss Albino Mice
}

\author{
MD. Ashrafuzzaman, $\mathrm{PhD}^{1}$; Golam Sarwar Raju; Muhammad Imam Uddin Abeer; \\ Saifuddin Mohammad Seeam²; Abu Zafor Mohammad Salahuddin'; Dipti Debnath ${ }^{3}$; \\ H.M. Shadid Hossain Snigdha ${ }^{4}$, Bhorhan Uddin Sawan²; S. M. Masud Rana ${ }^{1 *}$ \\ 'Department of Biomedical Engineering, Military Institute of Science and Technology (MIST), Dhaka, Bangladesh \\ ${ }^{2}$ Department of Pharmacy, Noakhali Science and Technology University, Noakhali, Bangladesh \\ ${ }^{3}$ Department of Pharmacy, Atish Dipankar University of Science and Technology, Dhaka, Bangladesh \\ ${ }^{4}$ Department of Pharmacy, University of Rajshahi, Rajshahi, Bangladesh
}

\begin{abstract}
Background: Different parts of Allamanda neriifolia (AN), Crinum latifolium (CL), and Bruguiera cylindrica (BC) are used in folk medicine to treat diarrhea. Therefore, the aim of this study was to investigate and compare possible antidiarrheal activity of the crude extracts from barks, stems, and roots of AL, CL, and BC in Swiss albino mice.

Methods: Antidiarrheal activities of extracts were evaluated at three doses $(100 \mathrm{mg} / \mathrm{kg}, 200 \mathrm{mg} / \mathrm{kg}$ and $400 \mathrm{mg} / \mathrm{kg})$ and compared with Loperamide in a castor oil-induced diarrhea and charcoal meal test model in the Swiss albino mice.

Results: The aqueous extract of CL and BC administered at doses of 100, 200 and $400 \mathrm{mg} / \mathrm{kg}$ showed $0 \%, 24.5 \%, 62.26 \%$ and $5.66 \%, 37.11 \%$, and $62.26 \%$ diarrhea inhibition, respectively. This reduction in diarrheal episodes is significant, and maximum effect was observed at the dose of $400 \mathrm{mg} / \mathrm{kg}$ similarly in the alcohol extracts of both CL and BC. AN administered at the dose of 100,200 and $400 \mathrm{mg} / \mathrm{kg}$ showed $55.97 \%, 74.84 \%$ and $74.84 \%$ diarrhea inhibition, respectively. The aqueous extracts of AN, CL and $\mathrm{BC}$ were able to increase the percentage inhibition of the charcoal meal movement.

Conclusion: The antidiarrheal effect of the $\mathrm{AN}$ extract, in contrast to $\mathrm{CL}$ and $\mathrm{BC}$, against the castor oil-induced diarrhea model prove its efficacy in an extensive range of diarrheal conditions.(Int J Biomed. 2016;6(3):233-236.).
\end{abstract}

Key Words: Allamanda neriifolia • Crinum latifolium • Bruguiera cylindrica • antidiarrheal activity.

\section{Introduction}

Diarrhea is one of the leading death-causing diseases, especially in developing countries, so this is the most concerning issue for these countries. In view of this, WHO has initiated a Diarrheal Disease Control Program to study traditional medical practices and other related aspects. ${ }^{[1]}$

Children are more susceptible to this disease, which is the second leading cause of death of children under five years old. ${ }^{[2]}$ The major causative agents of diarrhea in humans include Shigella flexneri, Staphylococcus aureus, Escherichia coli, Salmonella typhi, and Candida albicans. ${ }^{[3,4]}$ Diarrhea is a

*Corresponding Author: S. M. Masud Rana. Department of Biomedical Engineering, MIST, Dhaka, Bangladesh. E-mail: ripon. quit@gmail.com gastrointestinal tract (GIT) dysfunction, which is considered as a common symptom of infection and one of the causes of intestinal motility disorder. ${ }^{[5]}$ It causes loss of water and important nutrients from GIT in addition to increasing intestinal motility ${ }^{[6]}$ The rate of material movement through the intestinal lumen is directly associated with its motility. As diarrhea causes high intestinal motility, the increased motility also heightens diarrheal effects through increasing the rate of movement of intestinal content. ${ }^{[7,8]}$

Castor oil is known to induce GIT enteropooling similar to that observed in diarrhea ${ }^{[9-11]}$ Its effect is mediated by ricinolic acid, which can induce a hypersecretory response from the gut wall, leading to diarrhea. ${ }^{[12-14]}$ For this present study, three medicinal plants were selected and tested as antidiarrheal plants. The general information about these plants are shown in Table 1. 
Table 1.

General information about Allamanda neriifolia, Crinum latifolium and Bruguiera cylindrical

\begin{tabular}{|c|c|c|c|}
\hline Plants & Local Name & Family & Traditional Use \\
\hline $\begin{array}{l}\text { Allamonda } \\
\text { neriifolia }\end{array}$ & Gonta & Apocynaceae & $\begin{array}{c}\text { Antifungal and } \\
\text { antibacterial agent, } \\
\text { cathartic. }\end{array}$ \\
\hline $\begin{array}{l}\text { Crinum } \\
\text { latifolium }\end{array}$ & Sukhdarshan & Amaryllidaceae & $\begin{array}{c}\text { Rheumatism, fistula, } \\
\text { tumors, earaches, } \\
\text { rubefacient, tubercle and } \\
\text { whitlow agent. }\end{array}$ \\
\hline $\begin{array}{l}\text { Bruguiera } \\
\text { cylindrica }\end{array}$ & $\begin{array}{c}\text { Bakau Putih } \\
\text { (Oriya) }\end{array}$ & Rhizophoraceae & $\begin{array}{c}\text { Bleeding stopper and } \\
\text { blood pressure controller. }\end{array}$ \\
\hline
\end{tabular}

\section{Materials and Methods}

\section{Plant material}

The bark, stem and leaves of these plants were collected in Bangladesh. Allamanda neriifolia and Crinum latifolium were collected from the rural area of the Noakhali region and Bruguiera cylindrica from Sonadia Island, off the coast of Cox's Bazar. The plant material was originally identified and authenticated by the Bangladesh National Herbarium, Dhaka.

\section{Preparation of the plant extracts}

The bark, stem and leaves were washed under a running tap to remove adhered dirt and then dried in shade at a temperature between 21 and $30^{\circ} \mathrm{C}$ for 15 days. After complete drying, these were ground into fine powders. The $400 \mathrm{~g}$ of each powdered crude plant was subjected to a cold extraction process by maceration with $2000 \mathrm{ml}$ of $98 \%$ methanol at room temperature for 7 days. At the end, each macerate was filtered with Whatman No.1 filter paper, and the filtrate evaporated to dryness using a rotary evaporator (Buchi 011, USA). Residue left at the bottom of the beaker after evaporation was crude methanol extract of Allamanda neriifolia, Crinum latifolium, and Bruguiera cylindrica. The filtrate was air dried and stored in a refrigerator at $4^{\circ} \mathrm{C}$ for further testing.

\section{Experimental Animal}

Swiss albino mice of both sexes, aged 4-5 weeks, collected from Jahangirnagar University Animal House were used for the experiment. The animals were housed in polypropylene cages $(30 \mathrm{~cm} \times 20 \mathrm{~cm} \times 13 \mathrm{~cm})$ in standard conditions (room temperature $21 \pm 1.0^{\circ} \mathrm{C}$ and a 12-hr light/dark cycle) for 7 days before the experiment. The animals were fed with a standard diet and water ad libitum. The experiment was done in the Physiology Laboratory of University of Dhaka.

\section{Preparation of Test Materials}

Antidiarrheal activities of extracts were evaluated at three doses (100 mg/kg, $200 \mathrm{mg} / \mathrm{kg}$ and $400 \mathrm{mg} / \mathrm{kg})$. Administering the crude methanolic extracts of Allamanda neriifolia, Crinum latifolium and Bruguiera cylindrica at noted doses required the amount of each extract to be measured and triturated in a unidirectional way by the addition of a small amount of suspending agent Tween-80. After proper mixing of extracts and the suspending agent, normal saline was slowly added. The final volume of the suspensions made was $2.5 \mathrm{ml}$. To stabilize the suspension, it was stirred well by a vortex mixer.

\section{Antidiarrhoeal activity \\ Castor oil-induced diarrhea}

This experiment was carried out by the slightly modified procedure previously described by Uddin et al. ${ }^{[15]}$ and Awouters et al. ${ }^{[16]}$ In this method, castor oil is used to induce diarrhea in all the experimental groups. Defecation is the primary way to measure the antidiarrheal effect. Each animal was constantly observed for consistency of fecal matter and frequency of defecation. The feces were collected with an absorbent sheet of paper placed beneath the transparent cages. ${ }^{[16]}$ The wet feces were read at the end of the experiment by lifting up the upper part of the cage containing the sheet of paper and animals. The percentage inhibition of defection was measured using the following formula:

$\%$ Inhibition of defecation $=(1-\mathrm{B} / \mathrm{A}) \times 100$, were

A - Mean number of defecation by castor oil

B - Mean number of defecation by drug or extract

\section{Experimental Design}

Fifty-five mice were randomly divided into groups consisting of 5 mice in each group and fasted overnight before the experiment. Each group received a particular treatment. Prior to any treatment, each mouse was weighed properly and the doses of the test samples and control materials were adjusted accordingly. As it was difficult to observe the biological response of 5 mice at a time receiving the same treatment, it was necessary to identify individual animals of a group during the treatment. Each animal's tail was numbered with a marker to distinguish it from the others and marked as M1, M2, M3, M4, and M5. (Fig.1)

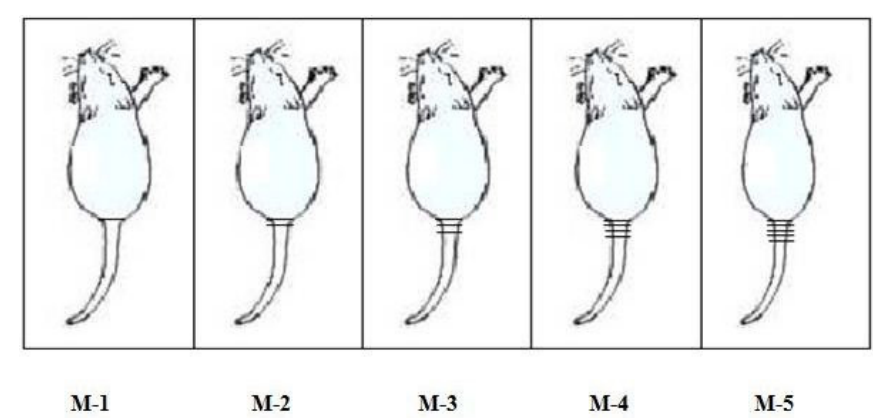

Fig. 1. Identification of test animals

\section{Procedure}

On the day of the experiment, the animals were divided into groups of 5 mice each. Control group (I) received 1\% $\mathrm{v} / \mathrm{v}$ Tween-80 in normal saline, $0.5 \mathrm{ml} / \mathrm{mice})$; Positive control group (II) received Loperamide (Square Pharmaceuticals Ltd., Bangladesh, $5 \mathrm{mg} / \mathrm{kg}$ body weight). Other groups received crude extracts of selected plants at different doses.

Thirty minutes after the administration of the controls and test samples, $0.5 \mathrm{ml}$ of castor oil was administered to each animal orally. The animals were placed in transparent cages 
to observe for consistency of fecal matter and frequency of defection for four hours. After 4 hours, the total number of defecations for each mouse was taken, and then the data were evaluated statistically to find their significance. Each mouse of all groups was observed for consistency of fecal matter and frequency of defecation. The percentage inhibition of defection was calculated.

\section{Intestinal motility test}

A gastrointestinal (GI) motility test was done according to standard methods ${ }^{[7,17]}$ with slight modifications. Control group I received $0.2 \mathrm{ml}$ PSS. Group II (positive control) received atropine sulfate $(5 \mathrm{mg} / \mathrm{kg})$. Effect of the extracts on intestinal motility was evaluated at three doses $(100 \mathrm{mg} / \mathrm{kg}$, $200 \mathrm{mg} / \mathrm{kg}$ and $400 \mathrm{mg} / \mathrm{kg}$ ). All administrations were made orally by gavage. Mice were given $1 \mathrm{ml}$ of charcoal meal ( 5 $\mathrm{g}$ of activated charcoal suspended in $50 \mathrm{ml}$ PSS) 30 min later through the same route. After another 30 minutes of charcoal treatment, animals were sacrificed in compliance with the NIH Guide for the Care and Use of Laboratory Animals. The distance traveled by the charcoal meal from pylorus to cecum was measured, and the percentage of inhibition of movement was calculated. ${ }^{[18]}$

\%Inhibition=(MTLI-MDCC)/MTLI x100, were MTLI - mean total length of the intestine and MDCC - mean distance covered by the charcoal

Statistical analysis was performed using StatSoft Statistica v6.0. Baseline characteristics were summarized as frequencies and percentages for categorical variables and as mean \pm SEM for continuous variables. Multiple comparisons were performed with one-way ANOVA and post-hoc Tukey HSD test. A probability value of $P<0.05$ was considered statistically significant.

\section{Results}

The acute toxicity study showed that oral administration of alcohol and aqueous extracts of Crinum latifolium and Bruguiera cylindrica up to $200 \mathrm{mg} / \mathrm{kg}$ dose showed neither mortality nor any visible clinical signs of general weakness in the animals. The aqueous extract of Crinum latifolium and Bruguiera cylindrica administered at doses of $100 \mathrm{mg} / \mathrm{kg}$, $200 \mathrm{mg} / \mathrm{kg}$ and $400 \mathrm{mg} / \mathrm{kg}$ showed $0 \%, 24.5 \%, 62.26 \%$ and $5.66 \%, 37.11 \%$, and $62.26 \%$ diarrhea inhibition, respectively (Table 2). This reduction in diarrheal episodes is significant, and maximum effect was observed at the dose of $400 \mathrm{mg} / \mathrm{kg}$ similarly in the alcohol extracts of both Crinum latifolium and Bruguiera cylindrica. Allamanda neriifolia administered at the dose of 100, 200 and $400 \mathrm{mg} / \mathrm{kg}$ showed $55.97 \%, 74.84 \%$ and $74.84 \%$ diarrhea inhibition, respectively. This shows significant reduction in diarrheal episodes with maximum effect at $200 \mathrm{mg} /$ $\mathrm{kg}$ and $400 \mathrm{mg} / \mathrm{kg}$ dose level. In Group II, Loperamide showed a significant reduction in diarrheal episodes by $54.72 \%$. The study reveals that the aqueous and alcohol extracts exhibited significant diarrheal activity. The antidiarrheal effect of the Allamanda neriifolia extract, in contrast to Crinum latifolium and Bruguiera cylindrica, against the castor oil-induced diarrhea model prove its efficacy in an extensive range of diarrheal conditions.
Table 2.

Effect of methanol extract of Allamanda neriifolia, Crinum latifolium, Bruguiera cylindrica on castor oil-induced diarrhea in mice

\begin{tabular}{|c|c|c|c|c|}
\hline Group/Treatment & Dose (p.o.) & $\begin{array}{l}\text { Number } \\
\text { of stools }\end{array}$ & $\begin{array}{c}\text { Inhibition } \\
(\%)\end{array}$ & Statistics \\
\hline Control group I & $\begin{array}{l}0.5 \mathrm{ml} / \\
\text { mice }\end{array}$ & $5.3 \pm 1.18$ & & \\
\hline $\begin{array}{l}\text { Control group II } \\
\text { (loperamide) }\end{array}$ & $5 \mathrm{mg} / \mathrm{kg}$ & $2.4 \pm 0.26$ & 54.72 & $P_{I-I I}=0.000$ \\
\hline $\begin{array}{l}\text { Allamanda neriifolia } \\
\text { (1a) }\end{array}$ & $100 \mathrm{mg} / \mathrm{kg}$ & $2.3 \pm 0.33$ & 55.97 & $\begin{array}{l}P_{I-1 a}=0.000 \\
P_{1-2 a}=0.000 \\
3-9 \\
0.000\end{array}$ \\
\hline $\begin{array}{l}\text { Allamanda neriifolia } \\
\text { (1b) }\end{array}$ & $200 \mathrm{mg} / \mathrm{kg}$ & $1.3 \pm 0.66$ & 74.84 & $\begin{array}{l}P_{I-l b}=0.000 \\
P_{I b-2 a}=0.000 \\
P_{1 b-2 b}=0.000 \\
P_{1 b-3 a}=0.000 \\
P_{1 b-3 b}=0.020\end{array}$ \\
\hline $\begin{array}{l}\text { Allamanda neriifolia } \\
\text { (1c) }\end{array}$ & $400 \mathrm{mg} / \mathrm{kg}$ & $1.3 \pm 0.33$ & 74.84 & $\begin{array}{l}P_{I-I c}=0.000 \\
P_{I c-2 a}=0.000 \\
P_{I c-2 b}=0.000 \\
P_{I c-3 a}^{I c-3 a}=0.000 \\
P_{I c-3 b}^{I C}=0.020\end{array}$ \\
\hline $\begin{array}{l}\text { Crinum latifolium } \\
\qquad(2 a)\end{array}$ & $100 \mathrm{mg} / \mathrm{kg}$ & $6.3 \pm 0.88$ & 0 & $\begin{array}{l}P I_{I-2 a}=0.000 \\
P_{2-2 b}=0.004 \\
P_{2 a-2 b}=0.000 \\
P_{2 a-3 b}^{2 a}=0.000\end{array}$ \\
\hline $\begin{array}{c}\text { Crinum latifolium } \\
(2 b)\end{array}$ & $200 \mathrm{mg} / \mathrm{kg}$ & $4.0 \pm 1.00$ & 24.53 & $P_{2 b-2 c}=0.020$ \\
\hline $\begin{array}{c}\text { Crinum latifolium } \\
(2 \mathrm{c})\end{array}$ & $400 \mathrm{mg} / \mathrm{kg}$ & $2.0 \pm 0.00$ & 62.26 & $\begin{array}{l}P_{I-2 c}=0.000 \\
P_{2 c-3 a}=0.000\end{array}$ \\
\hline $\begin{array}{l}\text { Bruguiera cylindrica } \\
(3 a)\end{array}$ & $100 \mathrm{mg} / \mathrm{kg}$ & $5.0 \pm 1.73$ & 5.66 & $P_{I I-3 a}=0.000$ \\
\hline $\begin{array}{c}\text { Bruguiera cylindrica } \\
(3 b)\end{array}$ & $200 \mathrm{mg} / \mathrm{kg}$ & $3.3 \pm 0.66$ & 37.11 & $P_{I-3 b}=0.020$ \\
\hline $\begin{array}{l}\text { Bruguiera cylindrica } \\
(3 c)\end{array}$ & $400 \mathrm{mg} / \mathrm{kg}$ & $2.0 \pm 0.00$ & 62.26 & $\begin{array}{l}P_{I-3 c}=0.000 \\
P_{3 a-3 c}=0.000\end{array}$ \\
\hline
\end{tabular}

Table 3.

Effect of methanol extracts of Allamanda neriifolia, Crinum latifolium, Bruguiera cylindrica on inhibition of GI motility

\begin{tabular}{|l|c|c|c|c|}
\hline \multicolumn{1}{|c|}{ Group } & $\begin{array}{c}\text { Dose } \\
(\mathrm{mg} / \mathrm{kg})\end{array}$ & $\begin{array}{c}\text { MTLI } \\
(\mathrm{cm})\end{array}$ & $\begin{array}{c}\text { MDCC } \\
(\mathrm{cm})\end{array}$ & $\begin{array}{c}\text { Inhibition } \\
(\%)\end{array}$ \\
\hline \multirow{2}{*}{ Group I } & $0.2 \mathrm{ml} \mathrm{PSS}$ & 42 & 30 & \\
\hline \multirow{2}{*}{ Group II } & $5 \mathrm{mg} / \mathrm{kg}$ & 37.1 & 32.5 & 12.4 \\
\hline \multirow{4}{*}{ Allamanda neriifolia } & $100 \mathrm{mg} / \mathrm{kg}$ & 39 & 24 & 38.5 \\
\cline { 2 - 6 } & $200 \mathrm{mg} / \mathrm{kg}$ & 40 & 26 & 35 \\
\cline { 2 - 6 } & $400 \mathrm{mg} / \mathrm{kg}$ & 40 & 27 & 32.5 \\
\hline \multirow{4}{*}{ Crinum latifolium } & $100 \mathrm{mg} / \mathrm{kg}$ & 43 & 21 & 51.2 \\
\cline { 2 - 6 } & $200 \mathrm{mg} / \mathrm{kg}$ & 42 & 22 & 47.6 \\
\cline { 2 - 6 } & $400 \mathrm{mg} / \mathrm{kg}$ & 39 & 26 & 33.3 \\
\hline \multirow{3}{*}{ Bruguiera cylindrica } & $100 \mathrm{mg} / \mathrm{kg}$ & 40 & 25 & 37.5 \\
\cline { 2 - 6 } & $200 \mathrm{mg} / \mathrm{kg}$ & 41 & 27 & 34.1 \\
\cline { 2 - 6 } & $400 \mathrm{mg} / \mathrm{kg}$ & 40 & 29 & 27.5 \\
\hline
\end{tabular}


Inhibition of GI motility by crude extracts of Allamanda neriifolia, Crinum latifolium and Bruguiera cylindrica is presented in Table 3. The studied extracts were able to increase the percentage inhibition of the charcoal meal movement.

\section{Discussion}

For present investigations, the castor oil-induced diarrhea model is used for the evaluation of the antidiarrheal property of drugs. Ricinoleic acid, the active component of castor oil, is responsible for its diarrhea-inducing property. ${ }^{[19]}$ It stimulates peristaltic activity in the small intestine, leading to changes in the electrolyte permeability of the intestine mucosa. Its action also stimulates the release of endogenous prostaglandins, which in turn stimulate motility and secretion. ${ }^{[20]}$ Medicinal plants are a promising source of antidiarrheal drugs. ${ }^{[21]}$ The present study showed that the methanol extracts of Allamanda neriifolia, Crinum latifolium, and Bruguiera cylindrica at a dose of $400 \mathrm{mg} / \mathrm{kg}$ exhibited a significant inhibition of castor oil-induced diarrhea in experimental mice, although $A N$ exhibited significant inhibition in all cases (100 mg, $200 \mathrm{mg}$ and $400 \mathrm{mg}$ ). Tanin, alkaloids, saponins, sterols and terpenoids present in plants are responsible for antidiarrheal activity. ${ }^{[21]}$ The above constituents may be present in the studied extracts. Further studies are needed to isolate the active substances from Allamanda neriifolia, Crinum latifolium and Bruguiera cylindrica for a clear understanding of the mechanisms of their actions.

\section{Competing interests}

The authors declare that they have no competing interests.

\section{References}

1. WHO. Diarrhoeal Diseases Control Programme: interim programme report 1988 (WHO/CDD/89.31).http:// apps.who.int/iris/bitstream/10665/126857/1/sea achr_15 inf.9.Pdf

2. Saralaya MG, Patel P, Patel M, Roy SP, Patel AN. Antidiarrhea activity of methanolic extract of Moringa oleifera Lam roots I experimental animal models. Int J Pharm Res. 2010; 2(2):35-39.

3. Toyin YM, Khadijat OF, Saoban SS, Olakunle AT, Abraham BF, Luqman QA. Antidiarrheal activity of aqueous leaf extract of Ceratotheca sesamoides in rats. Bangladesh J Pharmacol 2012; 7:14-20.

4. Krause R, Schwab E, Bachhiesl D, Daxböck F, Wenisch C, Krejs GJ, Reisinger EC. Role of Candida in antibioticassociated diarrhea.J Infect Dis. 2001;184(8):1065-9.

5. Maresca M, Mahfoud R, Garmy N, Kotler DP, Fantini J, Clayton F. The virotoxin model of HIV-1 enteropathy: involvement of GPR15/Bob and galactosylceramide in the cytopathic effects induced by HIV-1 gp120 in the HT-29-D4 intestinal cell line. J Biomed Sci. 2003;10(1):156-66.
6. Jimba Y, Nagao J, Sumiyama Y. Changes in gastrointestinal motility after subtotal colectomy in dogs. Surg Today. 2002;32(12):1048-57.

7. Qnais EY, Abdulla FA, Abu Ghalyn YY. Antidiarrheal effects of Juniperus phoenicia L. leaves extracts in rats. Pakistan Journal of Biological Sciences 2005; 8(6): 867-71

8. Hejazian SH. Morowatisharifabad M, Mahdavi SM. Relaxant effect of Carum copticum on intestinal motility in ileum of rat. World Journal of Zoology. 2007; 2(2): 15-18

9. Galvez J, Zavezuelo A, Crespo ME, Lorente MD, Ocete MA, Jimenez J. Antidiarrhoeic activity of Euphorbia hirta extract and isolation of an active flavonoid constituent. Planta Med. 1993; 59(4):333-6.

10. Gorard DA, Libby GW, Farthing, MJ. Ambulatory small intestinal motility in 'diarrhoea' predominant irritable bowel syndrome. Gut 1994; 35(2): 203-10.

11. Akomolafe RO, Adeoshun IO, Elujoba AA, Iwalewa EO, Ayoka AO. In vitro effects of Cassia sieberiena leave extracts on the intestinal motility of rats. African Journal of Biomedical Research. 2003; 6(1):141-5.

12. Capasso F, Mascolo N, Izzo AA, Gaginella TS. Dissociation of castor oil-induced diarrhoea and intestinal mucosal injury in rat: effect of NG-nitro-L-arginine methyl ester. Br J Pharmacol. 1994; 113(4):1127-30.

13. Chitme HR, Chandra M, Kaushik S. Studies on antidiarrhoeal activity of Calotropis gigantea R.Br. in experimental animals. J Pharm Pharm Sci. 2004 Feb 25;7(1):70-5.

14. Das AK, Rohini R, Hema A. Evaluation of anti-diarrhoeal activity of Rhizophora mucronata bark extracts. The Internet Journal of Alternative Medicine 2008; 7(1). http://print.ispub. com/api/0/ispub-article/3532.

15. Uddin SJ, Shilpi JA, Alam SM, Alamgir M, Rahman MT, Sarker SD. Antidiarrhoeal activity of the methanol extract of the barks of Xylocarpus moluccensis in castor oil- and magnesium sulphate-induced diarrhoea models in mice. $\mathrm{J}$ Ethnopharmacol. 20053;101(1-3):139-43

16. Awouters F, Niemegeers CJ, Lenaerts FM, Janssen PA. Delay of castor oil diarrhoea in rats: a new way to evaluate inhibitors of prostaglandin biosynthesis. J Pharm Pharmacol. 1978; 30(1):41-5

17. Meite S, N'guessan JD, Bahi C, Yapi HF, Djaman AJ, Guede-Giuna F. Antidiarrhoeal activity of the ethyl acetate extract of Morinda morindoides in rats. Tropical Journal of Pharmaceutical Research. 2009; 8(3): 201-207

18. Oben JE, Assi SE, Agbor GA, Musoro DF. Effect of Eremomastax speciosa on experimental diarrhea. African Journal of Traditional, Complementary and Alternative Medicine 2006; 3(1): 95-100

19. Roe DA. Diet and Drug Interactions. Chapter 6: Druginduced nutritional deficiencies. Springer; 1989, pp. 83-103

20. Pierce NF, Hirschhorn N. Oral fluid: a simple weapon against dehydration in diarrhoea: how it works and how to use it. WHO chronicle 1977; 31(3):87-93.

21. Zia-Ul-Haq M, Shahid SA, Muhammed S, Qayum M, Khan I, Ahmad S. Antimalarial, antiemetic and antidiabetic potential of Grewia aslatica L. leaves. Journal of Medicinal Plants Research 2012; 6(16):3087-92. 